\title{
Teaching Resources in Early School Grades: A Comparative Approach to the Teacher's Interpretative Space in Three Subject Areas
}

\author{
Florence Ligozat $^{1} \cdot$ Francia Leutenegger $^{1}$
}

Received: 23 September 2015/ Accepted: 15 October 2015/Published online: 20 October 2015

(C) Springer Science+Business Media Dordrecht 2015

\begin{abstract}
As a research field for studying the conditions of knowledge diffusion in teaching and learning, French-speaking Didactiques strongly rely upon the concept of knowledge transposition for characterizing the relationships between the knowledge built and used in "out of school" activities, the knowledge to be taught in the curriculum texts, and the knowledge effectively taught in the classroom. This paper explores the knowledge content and the learning epistemologies resulting from the transposition process by comparing teaching resources provided for the early grades (age 5-6) of primary school classrooms in western (French-speaking) Switzerland. We examined teaching resources from three subject areas: French language, mathematics, and science. The purposes of this study were two-fold: (i) to identify the early formation of subject areas in activities done with young students; and (ii) to uncover the implicit learning theories underpinning the patterns of teacher-student actions, according to the resources' designers. We found that a comparative approach to analysing teaching resources from different subject areas enabled us to trace the continuities and discontinuities in the teacher's interpretative space, defined by the textual description of the curriculum.
\end{abstract}

Keywords Curriculum $\cdot$ Teaching resources $\cdot$ School subjects $\cdot$ Didactic transposition $\cdot$ Joint action $\cdot$ Comparative didactics

Florence Ligozat

florence.ligozat@unige.ch

Francia Leutenegger

francia.leutenegger@unige.ch

1 Faculté de Psychologie et des Sciences de l'Education, Université de Genève, Uni-MAIL -

Boulevard du Pont d'Arve 40, Geneva 1205, Switzerland 


\section{Introduction}

Analyses of curriculum and material teaching resources displayed in classrooms have a long career in curriculum studies for discussing epistemological, social, and political rationales of school policies. Such studies often aim to provide guidance for curriculum reforms and to support practitioners in implementing a truly "new" curriculum. One research approach for studying knowledge diffusion in teaching and learning processes, French Didactiques, strongly relies upon the concept of knowledge transposition (Chevallard 1985/1991, Chevallard and Bosch 2014). This term characterises the relationships among the knowledge built and used in "out of school" activities, the knowledge to be taught in curriculum texts, and the knowledge actually taught in the classroom. Adopting a comparative standpoint, this paper examines the knowledge content and the learning epistemologies resulting from this transposition process, which are embedded in the texts of the teaching resources provided in the early grades (age 5-6) of primary classrooms in western (French-speaking) Switzerland. Drawing on the framework of teacher and student joint actions in didactics (Ligozat 2011; Ligozat and Schubauer-Leoni 2010; Sensevy 2014; Sensevy and Mercier 2007; also see Amade-Escot and Venturini; Sensevy, Gruson and Forest in this issue), we compared the teaching resources used in three subject areas: French language, mathematics, and sciences. The purpose in doing so was two-fold: (i) to identify the early formation of subject areas in the activities done with young students; and (ii) to uncover the implicit learning theories underpinning the patterns of teacher-student actions, according to the resources' designers. Adopting this comparative stance on the teaching resources used in different subject areas enables us to trace the continuities and discontinuities in the teachers' interpretative space, defined by the textual description of the curriculum.

\section{Teaching Resources, School Subjects and the Didactic Transposition}

There are many different ways in which educational research has analysed the material forms of the curriculum such as textbooks, methodologies, classroom worksheets, tests, etc. Such studies often focus on the knowledge content being presented to the students and the pedagogical directions given to the teachers in order to discuss the rationales for curriculum policies (Doyle 1992). These studies have enabled some international comparisons (e.g. Valverde et al. 2002, for mathematics and science), inspiring guidance for upcoming curriculum reforms. The need to support teachers when they experience new kinds of standard-based curricula (e.g. Principles and Standards for School Mathematics in the USA) has encouraged researchers to focus on the use of curriculum materials in classrooms. The implicit view of the teacher as a mere conduit for curriculum implementation is seriously questioned and a comprehensive approach to a teacher's instructional practices has been suggested (Remillard et al. 2009). In the 2000s, research in the French field of didactique des mathématiques (didactics of mathematics) also became interested in how various kinds of teaching resources may be used in the 
teaching practice. In examining the underestimated part of the teacher's work that is done outside of the classroom in France, Gueudet and Trouche (2009) suggest the notion of "documentational genesis" for describing the resources' influence on the teacher and the teacher's transformation of those resources. This approach insists on the fact that teachers are not mere readers or interpreters of texts and web resources, but they are also text producers of the documents that they create for teaching. In this vein, previous work (Ligozat 2011a) has suggested that the teaching designs elaborated by primary school teachers, which they draw from mathematics curriculum materials in western Switzerland, may be analysed with a triple set of determinants: (i) epistemic and ideological pre-constructs embedded the texts; (ii) professional thought styles shared among groups of teachers with similar approaches or backgrounds; and (iii) practical interpretative schemes arising from situated adjustments of the teaching design to meet certain broad institutional agendas. Based on this framework, this article will focus on the first set, i.e. the prefigurate aspects of teaching practice in various curriculum materials used in early school grades.

In most studies, teaching materials and their uses in the classroom are analysed from the perspective of single knowledge, domain-specific research in education (e.g. mathematics education, science education, language education, etc.). This is consistent with the focus on knowledge-domain specificity in educational research since the late 1970s. In the USA, Stevens et al. (2005) traced its origins back to (i) the shift from behaviourism to cognitivism, calling upon context-based problem solving (Glaser 1984); and (ii) the involvement of researchers trained in the related academic disciplines for analysing the learning of specific topics based on empirical research (Schoenfeld 1985, DiSessa 1982), the contents of secondary school curriculum (Schwab 1978), and for designing subject matter requirements in teacher-training programs (Schulman 1987). The move towards knowledge domainspecific research also occurred in Europe over several decades, with the growth of the French-speaking tradition of didactiques des disciplines (translated as "subject didactics"; Caillot 2007; Ligozat 2011b; Schneuwly 2011), the progressive autonomy of the German Fachdidaktiken (Vollmer 2014) in relation to the tradition of Allgemeine Didaktik (Meyer 2012), and similar developments in eastern European and Nordic countries (Englund 2006; Wickman 2012a; also see Ligozat et al. in this issue).

As a consequence of the growth of domain-specific research in education, comparative studies of the curriculum materials that the teacher uses in classroom actions, as well as the nature of the tasks and teaching units proposed in various subject areas, have received little attention. Among the rare studies comparing teaching practices across different subjects, Stodolsky (1988) found some significant differences in how the same fifth-grade primary school teacher modified social arrangements in the classroom depending on the subject taught during that part of the day. Stodolsky reports that time devoted to mathematics (as a subject) was spent merely constructing linear sequences systematically mapping the curriculum, whereas social sciences (as a subject) offered more opportunities for students' individual initiatives departing from the textbook. In mathematics, the teachers closely followed the textbook's guidance but in social sciences, the textbook served 
merely as a general context. An extension of this study, which looked at students' discourses about both these school subjects, (Stodolsky et al. 1991) also found some interesting distinctions: positive and negative experiences in mathematics were characterized in relation to the student's success or ability to do the work, while experiences in social sciences were described in terms of whether they were interesting or boring. Consistent with the teacher's use of textbooks, more students thought that they could learn the content of social sciences on their own, whereas few of them thought that they could learn mathematics in the same way.

In France, as in many other countries, studies in the various "didactiques des disciplines" (subject didactics) have explored the students' social representations of the subjects through questionnaires, interviews and analyses of classroom discourses (e.g. Audigier 1999). Adopting a comparative stance, Reuter (2007) explored how primary and secondary school students related their learning experiences to the "disciplines scolaires" (school subject areas). Reuter elaborated the concept of "conscience disciplinaire" (subject domain awareness) by including three interrelated dimensions that featured a distinctive subject domain in the students' discourses: contents (What did you learn this year in X?), purposes (According to you, why is $\mathrm{X}$ taught? What is it useful for?), and spatio-temporal indexicality of teaching and learning activities (How do you know that you are attending a lesson of $\mathrm{X}$ ?). Reuter came to the conclusion that some school subject forms are grasped by the students as early as the first grade of primary school (6-7 years old in France), which are increasingly deciphered by the students as they move up in grades, until the boundaries of school subjects become clear by secondary school. Interestingly, the higher achievers the students are, the better awareness of school subjects they have. These results call for a better understanding of the formation of school subjects, their limits, and benefits in research on teaching and learning practices, as suggested in Stevens et al. (2005).

In French didactiques, the organization of knowledge content into school subjects is theorized in the framework of the Anthropological Theory of Didactics (Chevallard 1992a, 1992b, 2007). First, the concept of didactic transposition (Chevallard 1985/1991; Chevallard and Bosch 2014) introduces a distinction between the bodies of knowledge as they are built and used in various out-of-school social activities (ranging from everyday life and professional practices to the scientific/academic practices producing scholarly knowledge) and the bodies of knowledge that are packaged for the specific purposes of teaching. Second, "knowledge" is conceptualised as complexes made of techniques and discourses about the techniques - namely "praxeologies" - that are connected to the problems and purposes of social organisations (institutions in Douglas's sense 1987). Hence, structuring a formal curriculum entails the construction of school-specific praxeologies, having a family resemblance with certain "out-of-school" praxeologies. Practically, this implies fragmenting the "big" questions that social organisations face (or have faced in the history of civilizations), selecting salient elements of answers (expressed as techniques, technologies, concepts and theories-see Chevallard and Sensevy 2014), and reconfiguring them into a series of topics organised into chapters, sections, sub-domains, domains, etc. The transposition operated by curriculum designers, educational researchers, teachers, etc. combines 
both the demands made by society on the schooling system and the specific constraints of this system. On the one hand, the knowledge-to-be-taught has to be legitimised by external actors (parents, politicians, academics, etc.) warranting its social pertinence and epistemological relevance. On the other hand, the knowledgeto-be-taught has to be communicable through texts and other semiotic forms, it has to be sequenced in time progressions, organised into subjects taught by different specialised teachers, assessed, etc. The formation and the boundaries of the different school subject domains - as macro-organisations of the knowledge-to-be-taughtresult from didactic transposition.

School subjects have complex relationships with academic disciplines (and the scholarly knowledge produced within), to which they are related to varying degrees. Schneuwly (2011) suggests that these relationships may be fruitfully understood from a double epistemological and historical perspective. On the one hand, disciplines can be described as social organizations aimed at producing and diffusing knowledge (Bourdieu 2001; Schwab 1978). Starting in the eighteenth century, the academic formation of disciplines remains an ongoing process, defining and redefining boundaries between disciplines by specialization, fusion and fission (Becher and Trowler 2001). On the other hand, the creation of school systems in nineteenth century in western countries has been characterized by a principle of unity: every part of the system is linked to all others, and the organization of the knowledge into "disciplines" (and/or school subject) is a means to achieve this unity - or at least to create the illusion of unity. Indeed, curriculum makers tend to present the knowledge to be taught at school as genuine: "It must appear that taught knowledge is not an invention of school. Although it cannot be a reproduction of scholarly knowledge, it should look like preserving its main elements" (Chevallard and Bosch 2014 p. 170). Yet unavoidably, the knowledge taught in schools is organised according to the rationales and purposes of the schooling systems. According to Chevallard, the role of comprehensive research in didactics is to take seriously the fallacy of "authenticity" in the knowledge transposition process. The purpose is not to improve authenticity, but to understand how the choices made by curriculum makers and teachers-generating gaps and shortcuts in praxeologiesmay facilitate or hinder teaching and learning in the classroom.

This perspective on the knowledge taught in schools has several consequences for our purposes here. The knowledge-to-be-taught packaged into texts and discourses embeds epistemological and educational values that may be found in programmes, methodologies, textbooks. The boundaries of school subjects must not, therefore, be taken as given categories by researchers: they vary across successive waves of curriculum reforms and national schooling institutions. They are historiccultural constructs that fit the constraints of society's demand to convey some part of human cultures to the younger generation. As such, they deserve to be studied as didactic means for teaching and learning with which young students need to be progressively acquainted; and from which older students completing their schooling need to be emancipated.

As the anthropologist Marcel Detienne states, "Providing they are not confused with origins, beginnings offer the considerable advantage of allowing one to observe phenomena that are at once less complex and more open than institutions in a more 
highly developed state" (Detienne 2008, p. 81). The French-speaking body of comparative didactics considers beginnings and transitions in the schooling process (e.g. from nurseries to pre-school grades, from primary to secondary schools, from schools to workplaces, etc.) as heuristic empirical samples for understanding the transposition process and its consequences in the classroom (Mercier et al. 2002).

\section{Curriculum and Teaching Resources in Western Switzerland}

In west Switzerland states, children enter the compulsory school system at 4 years old. Our study focuses on the beginnings of primary school (grade 1 and 2, i.e. 4-5 and 5-6 y.o.), ${ }^{1}$ where the overall aims in the core curriculum documents focus on strategies for acquainting young students to school culture. "The child enters school with the culture, the habits and the values conveyed by her/his family and community. To become a student, she/he will have to construe the tools favouring her/his learning and integration in the school world. The main objectives of this crucial step may be organised in three dimensions: socialisation, knowledge construction, cognitive tools acquisition"2 (Plan d'étude romand, ${ }^{3}$ Présentation générale, p. 24). The French-speaking states of western Switzerland have adopted a common core curriculum for the compulsory school grades ranging from grade 1 (4 years old) to grade 11 (15 years old) and divided into three parts (grade 1-4; grade 5-8; grade 9-11). Starting at first grade of compulsory school (4 years old), the western Swiss curriculum divides subjects into "languages", "mathematics and natural sciences", "arts" and "body and moves" (Plan d'étude romand, p. 25). Beyond learning to "live together", the expected socialisation targets learning to "learn together", for which the school subjects are presented as collective ways of doing and thinking in the school world.

An earlier study by Thevenaz-Christen and Schneuwly (2006) examining language activities in early grades in Geneva uncovered the beginnings of certain subject-specific forms for teaching reading and writing that continue in subsequent grades of primary school. In the present study, we are convinced that the development of subject-specific teaching practices in classrooms may be identified as early as the first grades of primary school. In primary school, since teachers do not have strong disciplinary training (compared to middle and high school teachers), the source of subject-specific practices may be found in the curriculum texts and teaching materials, as intermediate steps in the didactic transposition. Western Switzerland states provide a standardized set of teaching materials to all teachers for teaching the main subjects (namely the "Moyens d'enseignement"). It is therefore not a matter of teachers choosing among commercially available textbooks, although the standard teaching resources are often found to cohabit with other

\footnotetext{
${ }^{1}$ Until 2010, grade 1 and 2 (4-5 and 5-6 years old) used to be labelled as pre-school grades and were not compulsory. Nevertheless, these grades were attended massively in most states of western Switzerland.

2 All citations from documents written in French have been translated by the authors.

3 The Western Swiss study plan (Plan d'étude romand) is set up by the "Conférence Intercantonale des Directeurs de l'Instruction Publique (CIIP)". It is available online: http://www.plandetudes.ch/
} 
Table 1 Core curriculum texts and sample of teaching materials
Western Swiss study plan 2010 ("Plan d'études romand")

\begin{tabular}{|c|c|c|}
\hline $\begin{array}{l}\text { Learning objectives } \\
\text { "Languages" }\end{array}$ & \multicolumn{2}{|c|}{$\begin{array}{l}\text { Learning objectives } \\
\text { "Mathematics and Natural Sciences" }\end{array}$} \\
\hline \multicolumn{3}{|c|}{ Samples of standards teaching resources ("Moyens d'enseignement") } \\
\hline French Language & Mathematics & Sciences \\
\hline $\begin{array}{l}\text { Writing a procedural } \\
\text { text }\end{array}$ & $\begin{array}{l}\text { Measuring } \\
\text { lengths }\end{array}$ & $\begin{array}{l}\text { Distinguishing types of } \\
\text { wastes }\end{array}$ \\
\hline $\begin{array}{l}\text { "Le bricolage dle } \\
\text { Spot" }\end{array}$ & $\begin{array}{l}\text { "Maison de } \\
\text { pailles" }\end{array}$ & $\begin{array}{l}\text { "Pas n'importe où!" } \\
\rightarrow \text { Wastes! }\end{array}$ \\
\hline$\rightarrow$ Spot's Puppet & $\begin{array}{l}\rightarrow \text { The Straw } \\
\text { House }\end{array}$ & \\
\hline
\end{tabular}

teaching materials that teachers download from the web, for instance. Standard teaching resources are both a practical demand from the teachers and a suitable way for providing equal learning opportunities from the school authorities' perspective.

Hence, standard teaching resources in western Switzerland provide an interesting picture of the underlying assumptions of the curriculum enacted in the classroom. Comparing samples of resources available for teaching different subjects at early grades enables us to examine the knowledge transposition process at play in the formation of school subjects.

\section{Data Sources}

We conducted a comparative analysis of three samples of teaching resources (see Table 1), respectively chosen in each subject at grade 2 (5-6 years old): "Spot's Puppet" about writing a procedural text in the French language; "The Straw House" about measuring lengths in mathematics; ${ }^{5}$ and "Wastes" about the distinction of types of wastes in natural sciences. ${ }^{6}$

The selection of the teaching materials is based on the types of activities often reported in the students' portfolios in Geneva schools and previously analysed by one of the authors (Schubauer-Leoni and Leutenegger 2009). ${ }^{7}$ We selected three teaching resources involving hands-on activities for the students as a common departure point for our study. In the three resources, crafting, building or making an object (a dog puppet, a house, and fruit salad) is used as means for connecting

\footnotetext{
${ }^{4}$ Le bricolage de Spot. Activité de lecture-écriture $2 \mathrm{H}$ (Français I), cahier n 43, Service du Français, Département de l'instruction publique, Genève.

5 Maison de Pailles. Mathématiques, 1-2H, Livre de l'enseignant, Département de l'instruction publique, Genève.

${ }^{6}$ Pas n'importe où! Sciences de la nature, 1-2H, Moyens d'enseignement romands http://www. plandetudes.ch

7 The portfolios were collected from several teachers involved in a collaborative research network "Réseau Maison des Petits" (2005-2009). This network is co-funded by the Geneva Departement of Public Instruction and the Faculty of Psychology and Educational Sciences at the University of Geneva.
} 
school activities with more practical and familiar objects and habits. This common feature enables us to study the ways in which certain subject-specific practices were supposed to develop according to the curriculum designers.

\section{Analytical Framework: Teaching and Learning as Joint Actions Within the Didactic Transposition}

In order to proceed with a comparative analysis of the teaching materials chosen in French language, mathematics, and science, we used a common set of analytical categories behaving as tertium comparationis (third comparing term) among the resources to be compared (Mercier et al. 2002). The categories used stem from the framework of the analysis of the teacher and student joint action in didactics (Ligozat 2011; Ligozat and Schubauer-Leoni 2010; Sensevy 2014; Sensevy and Mercier 2007; also see Amade-Escot et al. and Forest, in this issue).

The teacher and student joint action framework is an attempt to grasp the logics of teacher and student actions as a continuation of the knowledge transposition process in the classroom. The teacher's task is to convey a pre-existing culture defined in the curriculum texts by planning lessons and managing didactic designs (or "primitive milieus") from which meaning-making takes place jointly with the students (Ligozat et al. 2011; also see Amade-Escot and Venturini in this issue). An important feature of the didactic joint action framework is that the teacher's and the students' mutual adjustment of lines of actions in the meaning-making process is regulated by the didactic contract (Brousseau 1997; Warfield 2014), i.e. the mutual responsibilities that the teacher and the students have towards each other. The dissymmetrical status of the teacher and the student with respect the proximate and ultimate purposes of classroom activities (Wickman 2012b) shapes the division of the work (topogenesis) and the direction that learning takes over time (chronogenesis). The teacher is supposed to orient the student's actions in order to help him/her learn, as well as to manage a common ground of meanings featuring the learning progression.

To a certain extent the teaching resources provided to the teachers by the school institution pre-figure certain dimensions of the didactic joint actions that will take place in the classroom. In early grades, these texts are addressed to the teacher exclusively, since there is no textbook for young students (only worksheets may be used with the students). The teaching resources are the written texts of envisioned teaching practices and learning outcomes, sometimes including explanations or justifications of the choices made, according to the designers.

In the present study, we analysed (i) the system of objects (physical, verbal, scriptural, etc.) and tasks featuring a primitive milieu in which teacher-student joint action takes place and from which certain new meanings may be construed by the students according to the designers; (ii) the teacher's role and responsibilities in managing the milieu, the social division of the work, and time progression; (iii) the responsibilities assigned to individual students as well as their peers in progression of learning; and (iv) the role of the group and the individual in producing institutionalised instances of knowledge. 
As suggested by Mercier (2008), analysing the nature of the tasks in teaching resources, i.e. the problematic situation that the task creates for the participants (students and teacher), provides a bottom-up insight about the transposition at work in schools. In addition, examining the pre-figurate patterns of teacher-student joint actions unveils the learning epistemologies conveyed by the texts of the teaching resources, as potentially enacted forms of the didactic transposition in the classroom.

\section{Results}

\section{Analysis of a Sample of Teaching Resource for French Language: Spot's Puppet}

"Spot's Puppet" is a teaching unit presented in a forty-five page booklet for grade 2 including general aims, step-by-step pedagogical instructions for each part of the unit, and some samples and worksheets to be shown to the students. There are actually several teaching resources based upon Spot the Dog series of books for children, in which different genres of texts are produced in oral or written forms (narratives, explanatory, convincing/advertising, etc.). According to the designers, this unit aims to "acquaint the students with observing, reading and writing a set of instructions to craft an object". From the students' perspective, the activity is finalized by writing a text to "explain to another student how to craft an articulated puppet of Spot the Dog" from pieces of cardboard (see Fig. 1). At grade 2, the young students do not master reading and writing skills sufficiently for writing the instructions themselves; they must orally dictate the text to the teacher.

The teaching unit is spread over several sessions in time. First, the students make the puppet, and they have to explain each step orally. Second, under the guidance of the teacher, the classroom collectively observes (the articulated model of the puppet, the materials used, examples of instructions), formulates (the instructions to be given), and distinguishes the textual components in similar kind of texts (title, subtitles, lists of materials, pictures, sentences starting with verbs, etc.), which structure a procedural text. At different steps, each student is supposed to use the knowledge built as a group in order to achieve some individual assignments on

Fig. 1 A model of the puppet "Spot the Dog" (excerpt from the booklet)

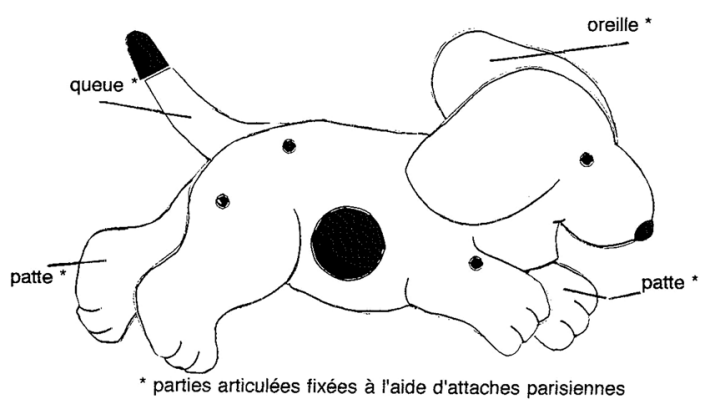


worksheets. Finally, the individual skills developed are re-invested into collectively constructing the text through oral dictation of a procedural text.

\section{The Nature of the Tasks}

The instructions for crafting Spot's puppet is to be thought out for "a friend who is not in the class". The text produced should be accurate enough to enable another student to make the puppet. Hence, the task of writing a text is functional. Knowing about the characteristics of procedural texts (among other textual genres) enables the student to take part in a collectively shared practice of communication. In this teaching unit, the socio-cultural dimensions of communication with texts, as well as the specific aspects of procedural texts (title, list of materials, list of actions with infinitive verbs, temporal adverbs, bullet point lists, numbers, etc.) feature the didactic transposition of a language practice that may be identified in kitchen recipes, guidelines for building a bookshelf, or health and safety recommendations. However, to what extent is the whole succession of tasks purposeful for the students? It starts with a hands-on activity (crafting a puppet), but rapidly the purpose becomes strongly oriented towards the textual characteristics of procedural texts to be distinguished from other types of texts, rather than playing with the puppet itself. The individual exercises focus on that knowledge, enabling the discrimination between and the complementarity of titles and sub-titles, the possible numbering of steps to follow, the drawings or images required for a series of steps to follow versus pictures for making the text attractive. In doing this, students encounter a variety of examples of instructions for crafting objects (a pencil box, a ladybird, a jigsaw, a mask, etc.). However, the numerous examples of procedural texts also have a dispersive effect: at some point the students may forget the steps for crafting the puppet of Spot the Dog, if not the overall project of writing a set of instructions.

\section{The Pre-figurate Patterns of the Teacher and Student's Responsibilities}

There is an iterative process involving collective and individual tasks so that the individual student does not work out the characteristics of the procedural text alone. The exercises break down the different sub-contents of the procedural text in order to work on them separately. However, the student has to re-organise the pieces of knowledge into a syncretic whole to achieve the objective of writing a text for explaining how to craft the Spot the Dog puppet. In this organisation, an underlying learning epistemology is that group work provides individual students with some "ways of doing" (habits, techniques) in using language that he/she would not be able to construct by him/herself. The teacher's responsibility is to support each student in appropriating these new habits. The discussion among peers about the specific characteristics of the procedural texts versus the general characteristics of texts (made of words, title, paragraphs, indication of the authors, etc.) is decisive in order to identify the principles for writing a procedural text. Peers contribute to the shared collective experience about each type of task in the unit, which becomes a resource for further individual actions. The pattern of this organisation is supported 
by a socio-cultural epistemology of learning, acknowledging that language actions performed by individuals necessarily stem from collectively shared language practices. The cultural mediation is provided by the artefacts (examples of procedural texts), in which the teacher points out the important aspects of the text. Supported by the numerous studies being done in the field of French language didactics in Geneva (Bronckart 1997; Schneuwly and Dolz 2009; ThevenazChristen \& Schneuwly 2006), this approach is consistent with a Vygotskian historiccultural epistemology of teaching and learning as a motor of human development (Schneuwly 1994).

\section{Analysis of a Sample of Teaching Resource in Mathematics: The Straw House}

The Straw House is a teaching resource presented on a double page of the mathematics textbook for grades 1 and 2. The same presentation format is used for other resources, organised into large segments: problem solving, forms and geometrical transformations, space mapping, numbers and operations, measurement. For each unit, the teachers are supposed to select and plan the succession of several activities in time. The Straw House teaching resource belongs to the unit on measurements and it aims at "using non-standard means of measurement," according to the designers. For the students, the activity is completed by the building of a house with linear straws, "the same as the model" presented on the blackboard (and more particularly a house with a sloped roof-see Fig. 2). At grade 2 , measuring with a ruler marked with standard units is not yet a learning objective. Instead, the goal is for young students to perceive lengths as quantities that can be compared and represented by various artefacts.

The teaching unit related to this resource may be achieved in a couple of sessions, possibly during a same day. First, each student is supposed to attempt the task alone (one house should be made by each student) with the techniques that he/ she already knows about building an object according to a model and making a collage. Second, the teacher organises a classroom meeting in which each student can compare his/her house with to those made by peers in order to sort it into one of three categories suggested by the teacher (houses that closely resemble or somewhat

Fig. 2 Materials used for the Straw House activity (excerpt from the textbook)

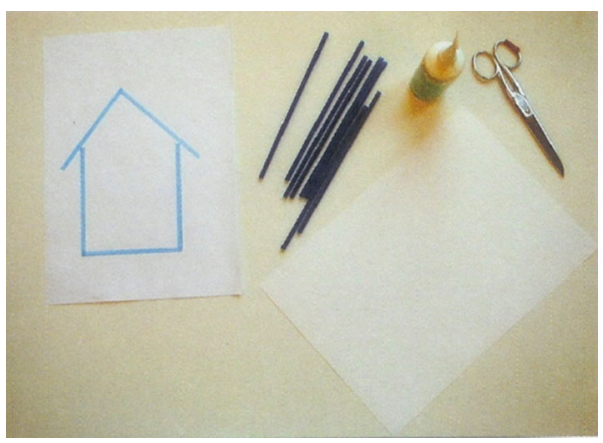


resemble or do not resemble the model). In doing this, the student may explain how he/she proceeded. Then, a discussion takes place to elicit the relevant techniques to make a house that closely resembles the model. Later, students may be invited to try the same type of task with a different model (a boat for instance) and with different tools (strings or plasticine). At this stage, proofing techniques may be used to avoid the need for further classroom meetings: "the students validate their own construction by placing the moulded sticks of plasticine onto the model", according to the designers.

\section{The Nature of the Tasks}

During the individual attempt at the problem, the knowledge to be construed concerns practical means to replicate the lengths of the segments in the house model and spatial organisation of the straws on the worksheet. The straws may be marked, folded or cut to translate the lengths of the segments in the model. Straws play the role of "carriers" of a quantity, functioning as a measuring tool. The distance between the models displayed on the blackboard and the sheet of paper on the student's table requires the representation of the lengths as measurable quantities featuring the house. This latter condition creates a functional situation for measuring, as replicating a quantity. This situation transposes certain types of problems that humans faces in delineating spaces for social uses (building maps and roads, dividing land into agricultural fields, designing various architectural structures, etc.). Historically, these problems led humans to elaborate tools for representing object configurations in space and transforming them (geometrical shapes and transformations), that conserve the quantities. Ratios, numbers, and measuring units are the numerical tools for representing and working with quantities. In this classroom activity, representing the side lengths of the house with the straws is the first step in using measuring units. However, the purpose behind using the straws in this manner may not be immediately clear from the students' actions. To what extent is the individual attempt to the problem "individual"? Many actions carried out by peers may be observed and invested by the individual student. Should the teacher encourage interactions between students so they can share ideas? Should the teacher remind students about previous and/or tacit knowledge about quantity conservation and comparison tasks nested in the classroom's collective memory? The primitive milieu envisioned by the designers may be augmented with teacher and peers' inputs in order to facilitate a student's involvement in the task. Furthermore, the classification of the houses built by the students is not trivial. The status of the "resemblance" between houses built and the model may be interpreted in different ways that do not necessarily rely upon measurement techniques. The students may have used a fruitful measuring technique for reproducing lengths, but the results may be classified as "somewhat resemble" or "do not resemble" if the straws are not disposed in the same geometrical configuration (with their parallel and perpendicular properties). The teaching resource supposes that the teacher has elaborated a deep understanding of the range of possible student actions at the first step of the task, to introduce a distinction between relevant measuring techniques and the relevant spatial techniques for assembling the straws. 


\section{The Pre-figurate Patterns of the Teacher and Student's Responsibilities}

The teacher's actions described by the designers focus on setting up the most favourable situation by organising the material components (dimensions of the model, distance between the model and the table where the collage is made, the number and length of the straws displayed, strings and eventually the rulers available upon request). However he/she is not supposed to intervene during the building of the house by the students. Then, the role of the classroom meeting is to provide a social context so that (i) the student can judge the adequacy of his/her production afterwards against the background of other houses made by peers and (ii) the successful or unsuccessful techniques used by individual students are elicited orally. In this organisation, an underlying learning epistemology is that the problematic task encountered and the artefacts constituting the primitive milieu should prompt the students to use the straws as "carriers" for replicating the lengths by themselves. Such logic prioritizes individual actions for adapting one's own techniques to solve a problem; then the new techniques may be formulated, deliberated and institutionalized within the group before they are practiced again in another session. This pattern relies upon the student's adaptation to the situation when confronted with the practical problem of reproducing the house without having the model at hand, on the table. This premise is consistent with a constructivist-adaptive epistemology of learning that may be traced back to Piagetian models of knowledge construction. In French didactics of mathematics, this epistemology of learning inspired Brousseau's theory of didactic situations (Brousseau 1997), in which the modelling of student-milieu relationships is a milestone for designing a functional didactic situation (see also: Brousseau and Warfield 2014).

\section{Analysis of a Sample of Teaching Resource in Science: Wastes!}

"Wastes!" is a teaching resource presented on a double page of the natural science textbook for grades 1 and 2. It is part of the section devoted to the "Exploration of natural and technical phenomena". According to the designers, this activity aims at "observing the biodegradability of certain wastes and relating types of wastes to the corresponding recycling workflows". From the student's perspective, the activity is anchored in making a fruit salad in the classroom and it evolves towards the question "Which bin should we put the wastes in?" This teaching resource targets at least two different types of content: the conceptual distinction between organic and non-organic matter (stemming from the distinction between living and non-living forms) and the social and environmental issues about managing wastes in society today. The teaching unit is supposed to unfold over one month with iterated sessions every week. After making the fruit salad, the students' attention is focused on the wastes generated: fresh fruit skins, tin cans, and paper labels (see Fig. 3).

First, the teacher asks the students to draw the wastes on a worksheet on which three different bins are pictured. The students are thus supposed to make a decision about which wastes can be put in the same bin or not. Second, the teacher invites the students to proceed to an intuitive exploration of the differences in matter between 
Fig. 3 Wastes to be tested: banana skin, tin can and paper label (excerpt from the textbook)

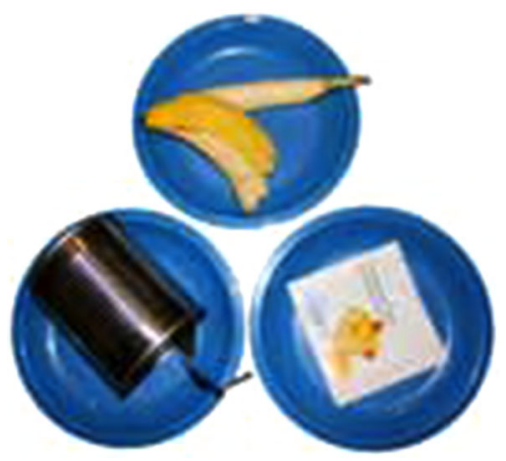

the three pieces of wastes by observing, touching, smelling them: "What are they made of?" is the driving question. Third, the teacher sets up an experiment to observe the changes undergone by different wastes over time. Each piece of waste is put in a distinctive open recipient (the storage conditions are not mentioned). The teacher takes a picture on the first day, and the students have to make some hypotheses about the possible changes in each piece of waste over a period of one week. A few days later, the wastes are observed again and the changes are reported on a timeline using a colour code (green sticker: there is a change; red sticker: there is no change; blue sticker: we do not know). Then new hypotheses are made, and so on. At the end of the month, a collective discussion takes place about the reports on the timeline to conclude about what types of wastes undergo change. Certain criteria for sorting the different pieces of wastes into three bins may be envisioned: matter (organic, metallic, paper), biodegradability (yes, no, maybe), other. The students then compare these criteria to their first sorting, and the teacher asks them to sort the wastes again on a new worksheet and to discuss the changes in their original hypotheses. A video on organic composting, for instance, may complement the unit.

\section{The Nature of the Tasks}

The role of the fruit salad is to raise questions on behaviours related to wastes. It functions as an everyday context. The rationales of the designers' choice to use wastes for elaborating the sorting criteria are not easy to grasp. Why suggesting sorting the wastes into three bins in the first step? If the students decide to put all the wastes having the same colour in the same bin, in what ways would the experiment change their mind? Simply storing the wastes inside the classroom may lead to the incorrect conclusion that only the fresh fruit skins change; whereas storing the wastes outside on the ground of the school yard provides a much more varied exposure to daylight, rain, soil, insects, etc. from which different conclusions may be drawn (the tin can oxidizes, the label paper fades and disintegrates when getting wet, the banana skin may be eaten by insects, etc.). If the purpose is to characterize the biodegradability of wastes as a criterion for sorting them into different bins, then the experiment requires natural environmental conditions. More generally, the suggested experiment is not functional for addressing the general question about the 
wastes of the fruit salad: "Which bins should we put wastes in?" If the only criterion considered is biodegradability, since there is no change observed over one month in the paper and the tin can, the paper and the tin can may be put together in the same bin. If the only criterion is matter, then the three types of wastes may be separated into three different bins. In the latter case, the experiment may not be needed. In order to decide which criterion should be used, industrial and ecological dimensions of human activities have to be taken into account. For instance, some wastes are not just put together because they are "made of paper", or because "they do not undergo quick changes over time", but also because they can be easily recycled in the same industrial workflow; because they may generate low-cost energy (e.g. producing gas combustibles), or because they have a strong impact on the environment and health (e.g. batteries filled with hazardous chemicals). Identifying the different matter and their biodegradability in order to sort wastes is only one of the multiple components in waste management. Thus, the suggested experiment in the teaching resource is a partial transposition of a broader body of knowledge on waste management. What are the consequences? The experiment may be functional for explaining the rationales for sorting organic/non-organic wastes, but it is not fully functional for establishing the criteria for managing wastes. At this point, it is possible to identify a tension among the different purposes that curriculum makers try to fit together, whereas these purposes are not causally related: teaching scientific concepts such as organic/non-organic matters, teaching environmental norms that students should be aware of, and using a supposed "good" pedagogical method for learning science that mimics of the inquiry practice of a scientist. In the resulting transposition, scientific inquiry appears to be a primary source for legitimating certain environmental norms.

\section{The Pre-figurate Patterns of Teacher and Student's Responsibilities}

Apart from the representations of the sorting of the wastes by each student at the beginning and the end of the unit, each step may be run collectively. This is a common pattern for most of the science units displayed in the manual. On the one hand, there is little space left for students' individual actions and decisions within the classroom collective. On the other hand, the teacher seems to have very few responsibilities in terms of highlighting the relevant outcomes of the experiment, whereas he/she is clearly the main orchestrator of the experiment. The teaching resource is designed as if the collective actions carried out during the experimentand the follow-up discussions-should necessarily result in the relevant learning objectives envisioned by the designers. It is worth to note that the designers indistinctively describe what the teacher's and the student's respective actions should be. Conversely to the French language and mathematics teaching resources analysed above, the text of the science resource is written as a merely projected scenario of the teacher's discourse in the classroom. Most of the text is devoted to the questions and instructions that are supposed to be directly addressed to the students (take a piece of waste... watch it carefully... what is it made of? can you smell anything for each of them? etc.). The actions that should take place are described in terms of collective imperative sentences (let's observe the pieces of 
waste today... let's put a coloured sticker to describe the banana skin... what were our hypotheses last week? etc.). There are no explanations or justifications of the teacher's role with respect to the students' actions and the learning outcomes.

In this organization, the structure of the scientific experiment dominates as an iterated loop (hypothesis, observation, and report) for addressing a question about everyday objects. There are two underlying learning epistemologies that can be identified in the text of this teaching resource: (1) practicing a collective scientific inquiry is a self-contained teaching method for transforming individual students' prior ideas and; (2) the scientific concepts (organic/non-organic compounds, biodegradability) elaborated during the inquiry should guide the citizen in making enlightened decisions about his/her impact on the environment. The first epistemology is consistent with the conceptual change approach of scientific learning through a guided discovery of scientific phenomenon. The second learning epistemology is consistent with a positivist attitude towards the outcomes of sciences as academic disciplines. This latter epistemology is part of the many messages that are given to teachers and students about the nature of science, functioning as side-contents or companion-meanings (Östman 1998).

In sum, for each teaching resource analysed, we have depicted the primitive milieus, the succession of tasks, and the learning outcomes according to the designers. Analysing the nature of the tasks enables us to study their potential epistemological continuity with respect to certain "out of school" human practices. Whereas the French language and the mathematics type of teaching task are continuous with certain socio-cultural human practices, the science task contains some discontinuities due to competing didactic purposes. However, the functionality of the tasks does not necessarily mean that the task is imbued with meanings from the students' perspective, if the didactic primitive milieu is too dispersive (the numerous examples of procedural texts in the case French language teaching resource) or if it contains gaps (the lack of natural conditions for observing the degradation of the matter in science). The characterisation of the pre-figurate patterns of teacher and student responsibilities reveals the different choices made by the designers about the connection between individual and collective actions in the classroom. This latter aspect informs us about the learning epistemologies related to the school subjects. These aspects are discussed in depth in the following section.

\section{Discussion of Results}

\section{Emergence of Subject Areas in Early Grade Classroom Activities}

Having analysed the data presented above, we now turn to discuss the formation of school subjects through the rationales of the teaching practices embedded in the teaching materials. The formation of the school subjects starting in the early grades of primary school is not just a "reduced reality" of secondary school subjects or academic disciplines. School subjects are institutional constructions that bring together certain types of tasks related to selected types of human practices and intertwined with more or less explicit theories of learning conveyed by educational 
research. Whether such learning epistemologies are relevant or not for efficient teaching and learning in the classroom goes beyond the scope of this article. Such a question would require an in-depth analysis of the actual classroom practices stemming from these materials. However, our comparative analysis of the subjectspecific teaching practices envisioned in the resource texts enabled us to delineate some specific and generic features of subject formation in classroom activities.

From the students' perspective, generic content is learnt from the experience of teaching units related to different school subjects: activities in the classroom have another purpose than activities that may be carried out in families, with friends, or in a leisure centre. Activities in the classroom are designed to build new ways of acting and thinking through an epistemic differentiation of tasks, which were characterizing the oral and written textual genres in the French language, solving geometrical problems in mathematics, and categorizing and modelling natural phenomena in science in our examples. Across the school subjects, young students progressively became acquainted with the fallacy of tasks that were supposed to be "authentic": crafting, building, making an object at school not for the purpose of using this object, but for learning some new power for acting in the world. This understanding, which occurs along with the progressive deciphering of the differences between subjects (Reuter 2007), is a condition for learning at school.

Starting with the crafting of a puppet, the building of a house made of straws, or the making of a fruit salad as proximate purposes, each teaching unit evolved towards building some new habits about everyday events and artefacts as ultimate purposes (Wickman 2012b). These habits included techniques for communicating in writing (Spot's puppet), for operating on material quantities (The Straw House), and for managing human impact on the environment (Wastes!). The students would not be able to make sense of each of these techniques if the teacher tried to describe them in advance. Rather, they have to experience a succession of tasks sequenced in time by the teacher in order to construe these techniques jointly with the teacher and to make sense of their functionalities to solve certain categories of problems. This time process, in which the content to be learnt unfolds in actions, is the very meaning of chronogenesis as an essential dimension of the continued didactic transposition in the classroom (Chevallard 1985/1991; Mercier et al. 2005). The second essential dimension of the continued didactic transposition in the classroom is topogenesis (Chevallard 1985/1991). For each task sequenced in time by the teacher, students have a certain level of responsibilities in construing meaning about it. This level of responsibility varies across time according to the nature of the content construed. The more the content construed by the students is consistent with the teacher's ultimate purposes, the higher the teacher may credit the level of student responsibility.

Since the teacher's ultimate purposes are driven by the curriculum objectives, the division of knowledge into subjects may be reflected by the teacher's specific interventions to orient the meanings construed by the students toward the content to be taught. In the case of the French language teaching resource, the envisioned teacher's interventions are clearly oriented towards the features of the procedural text to be written (title, subtitles, list of materials, numbers, verbs, etc.) at the various steps of the unit. In science, the teacher is supposed to point out some 
criteria for sorting the pieces of wastes at the end of the experiment in terms of matter and biodegradability, although we have shown that these criteria are not necessarily consistent with the actual needs and possibilities of the waste management in society. In the mathematics teaching resource, the teacher's interventions on the content construed by the students are not precisely detailed. The teacher is supposed to "elicit statements on what is the same or different" between the houses made by the students, as if the techniques for replicating lengths with the straws and organizing them spatially are self-evident.

\section{Learning Epistemologies at Play in the Curriculum}

These differences in the purposes of the teacher's interventions may be contingent. However, it is worth noticing that they are related to the learning epistemologies at play in general pedagogical recommendations.

Previous works by Schubauer-Leoni and Leutenegger (2009) have pointed to the socio-constructivist paradigm invoked for teaching and learning all subject matters by the curriculum makers in Geneva. However, Schubauer-Leoni \& Leutenegger also highlighted an important distinction between "knowledge constructed by means of social interactions and social transmission" and "knowledge constructed by the individual subject through his/her own actions" in the Geneva School Objectives set up in 2000 (Objectifs de l'Ecole Genevoise, Introduction, p. 3). In the first category of knowing, an explicit, even primordial, role is assigned to the teacher who initiates the process, whereas in the second category, the student's action is prioritized and the teacher is confined to the merely organising the conditions for learning. ${ }^{8}$

When considering the three samples of teaching resources analysed, the French language resource easily fits into the first category, whereas the mathematics resource is related to the second category. Without explicitly mentioning language as a school subject for the first category and mathematics for the second one, the part of the text on the "general conceptions of learning" describes the transmission language "through ready-made forms, imposed forms" requiring the "presentation by an adult in an organised and adapted manner" of knowledge to which the child is meant to attribute significance. In the second group, knowledge is related to "doing" and the text mentions "cognitive instruments" such as "comparison, classification, ordering, counting". In this perspective, the teacher does not present knowledge but he/she "judiciously chooses the learning situations", the person who "plans and organises structuring activities". In this case, the student "acts and talks about his or her actions" (ibid, p. 4). While both categories invoke the motivating role of peers, both ways of knowing are implicitly related to two distinctive categories of subjects: language and mathematics. Between these two options, however, it was not possible to categorise the patterns of the teacher and students responsibilities that we identified in the science teaching resource. This is not very surprising since these patterns are not well defined in the teaching resource either. In

\footnotetext{
${ }^{8}$ In contrast, the new western Swiss Study plan (2010) does not contain any specific discourses on the general learning epistemologies. However, since most of the standard teaching resources remain in use, the teachers' practices may be continuous.
} 
these resources, the learning epistemologies are more closely related to the epistemologies of academic science as a teaching tradition (Roberts 1998).

To understand the status of the learning epistemologies embedded in the natural science teaching resources, we need to look further into the pedagogical recommendations about teaching and learning sciences. Since the scientific contents are very diverse, they generate "various teaching practices". Hence, "at the free will of the teacher", science teaching practice "induces moments of collective, group or individual work" (Objectifs de l'Ecole Genevoise, Sciences, p. 3). The discourse is rather vague about the role of the collective and the attribution teacher and student responsibilities. This fits well with the indistinctive description of the teacher's and the students' respective actions in the teaching scenario. Not surprisingly, there is a strong emphasis on the scientific method (observing and experimenting) as the pillar for supporting the child in "changing" and "enhancing his/her mind" on everyday events and "deciphering a hidden reality" (ibid, p. 1).

In each case, the role of the collective is mentioned but for different purposes: in the case of written and oral language, the group is the source and the condition for getting acquainted with the social norms of communication; in mathematics, the collective functions as a socialising context for supporting the conceptualisation process; in science, possibly for developing argumentative skills in practicing the scientific method.

These different views on knowing a subject are rooted in seemingly contradictory learning epistemologies related to certain interpretations of work by Piaget and Vygotski. But how can a generalist teacher possibly make sense of these epistemologies in planning the successive subjects in the school day? DucreyMonnier (2014) compared the classroom practices of several teachers successively teaching French language and mathematics in early grades in western Switzerland. She showed that each teacher's ways of doing tended to be rooted in a single epistemology; they did not switch epistemology when changing from one subject to another.

One major outcome of the present study is that the learning epistemologies embedded in teaching resources tend to blur the epistemological features of the types of task in each subject. Indeed, an important distinction between the mathematic task on the one hand and the French language and science one on the other is that the former offers a self-contained problem to the students, that can be raised and solved from the trials developed by the classroom participants. However, this is only possible if the teacher organises some collective discussions about the trials to give them an adequate meaning related to the mathematical problem, i.e. $a$ discourse upon the techniques used has to be built. ${ }^{9}$ Knowledge construction in mathematics is not a matter of students finding solutions to problems on their own and then reporting them. In French language, the writing of a text depends on certain arbitrary socio-cultural criteria for shaping a procedural text that cannot be entirely rebuilt from the mere succession of learning tasks that the students have to address in order to explain to another student how to craft an articulated puppet of Spot the Dog. The teacher's input is thus necessary, but it does not have the same

\footnotetext{
9 A full praxeology in Chevallard's words (Chevallard and Sensevy 2014).
} 
function as in the mathematics task: the teacher has to bring in some cultural pieces of discourses about writing a procedural text, that cannot be produced by the mere students' activities about texts in the classroom. ${ }^{10}$ In science, since the experiment cannot fully warrant the actual criteria for waste management in society, the teacher's role is ambiguous. As for writing a procedural text in French, elaborating criteria for waste management is also far from the experience of the students in the classroom. Learning how to sort wastes is not a matter of conceptual change about categories of matter and habits about wastes. The teacher has to extend the results of the biodegradability experiment to the socio-cultural ways of sorting categories of wastes, in order set up new habits among the students.

The comparative stance adopted in this paper challenges the traditional view on school subjects as a "reduced reality" of academic disciplines. We have shown that the differences in school subjects in classroom practices rely upon the epistemological features of the praxeologies that may be built in the classroom from the task, rather than the learning epistemologies attached to them within the transposition process.

\section{Conclusion}

Analysing these teaching resources should not be understood as a criticism of curriculum texts but as evidence of the didactic transposition at work in schools. This process shapes the teacher's interpretative space of action opened up by the teaching resources, in which the practical logics of the teachers will be involved. This has been shown by Ligozat (2011a) and Marlot and Toullec-Thery (2014) in French-speaking research in didactics, as well as more generally by studies on the use of curriculum materials worldwide. In order to transform teaching practices during curriculum reforms, it is not enough to account for the ways in which teachers select and implement teaching resources. There is a stringent need for analysing the necessities and the potentials of learning tasks along with the teacher's supposed interventions in teaching resources, according to the curriculum makers. This is what Mercier (2008) termed a bottom up analysis of the didactic transposition, starting with the teaching resources as a product of the transposition and tracking the bodies of knowledge to be built from them, according to the logic of the practice.

To return to Chevallard's anthropological theory of didactics, if the knowledge to be taught in schools is not similar to the praxeologies in use in today's society, nevertheless the former has to be minimally continuous with the latter from the participants' perspective. At the end of the transposition chain, knowledge learnt has to be apt for helping the young generation face new challenges in society (Schubauer-Leoni and Leutenegger 2005). Modelling teacher-student joint actions as the continued transposition process in the classroom, has the potential to overcome the traditional, scattered ways of studying the institutional aspects of the curriculum, the learning outcomes of the teaching tasks encountered by the students,

\footnotetext{
${ }^{10}$ It took a long time for human societies to organise communication into genres of texts and types of discourses (Bronckart 1997).
} 
and the interactive patterns of teaching and learning in the classrooms. This perspective invites us to think of comparative didactics as research framework that breaks down boundaries, going beyond the scope of cumulative studies in subject didactics and/or domain-specific education.

Acknowledgments We would like to thank Alain Mercier (Aix-Marseille Université, France) for his helpful comments on this paper.

\section{References}

Amade-Escot, C. \& Venturini, P. (in this issue). Joint Action in Didactics and Classroom Ecology: Comparing Theories using a Case Study in Physical Education doi: 10.1007/s10780-015-9263-5.

Audigier, F. (1999). School disciplines, social representations, and the construction of the didactics of history, geography, and civics. Instructional Science, 27(1), 97-117.

Becher, T., \& Trowler, P. (2001). Academic tribes and territories: Intellectual enquiry and the cultures of discipline (2nd ed.). Philadelphia, PA: Open University Press.

Bourdieu, P. (2001). Science de la science et réflexivité. Paris: Raisons d'agir.

Bronckart, J.-P. (1997). Activité langagière, textes et discours: Pour un interactionisme socio-discursif. Sciences des discours, (Vol. 1-1). Lausanne: Delachaux et Niestlé, ISSN 1961-8379.

Brousseau, G. (1997). Theory of didactical situations in mathematics: Didactique des mathématiques, 1970-1990. Dordrecht: Kluwer (Springer).

Brousseau, G., \& Warfield, V. (2014). Didactic situations in mathematics education. In S. Lerman (Ed.), Encyclopedia of mathematics education (pp. 163-170). Netherlands: Springer.

Caillot, M. (2007). The building of a new academic field: The case of French didactiques. European Educational Research Journal, 6(2), 125-230.

Chevallard, Y. (1985/1991). La transposition didactique: Du savoir savant au savoir enseigné. Grenoble: La Pensée Sauvage

Chevallard, Y. (1992a). A theoretical approach to curricula. Journal für Mathematik Didaktik, 2(3), 215-230.

Chevallard, Y. (1992b). Fundamental concepts in didactics: Perspectives provided by an anthropological approach. In R. Douady \& A. Mercier (Eds.), Research in «Didactique» of mathematics. Selected papers (pp. 131-168). La Pensée Sauvage: Grenoble.

Chevallard, Y. (2007). Readjusting didactics to a changing epistemology. European Educational Research Journal, 6(2), 131-134.

Chevallard, Y., \& Bosch, M. (2014). Didactic transposition in mathematics education. In S. Lerman (Ed.), Encyclopedia of mathematics education (pp. 170-174). Dordrecht: Springer.

Chevallard, Y., \& Sensevy, G. (2014). Anthropological approaches in mathematics education, French perspectives. In S. Lerman (Ed.), Encyclopedia of mathematics education (pp. 38-43). Dordrecht: Springer.

Detienne, M. (2008). Comparing theiIncomparable (J. Lloyd, Trad.). Stanford: Stanford University Press.

DiSessa, A. (1982). Unlearning Aristotelian physics: A study of knowledge-based learning. Cognitive Science, 6, 39-75.

Douglas, M. (1987). How institutions think. London: Routledge and L. Kegan Paul.

Doyle, W. (1992). Curriculum and pedagogy. In P. W. Jackson (Ed.), Handbook of research on curriculum (pp. 486-516). New York: Macmillan.

Ducrey-Monnier, M. (2014) Étude comparatiste de leçons de français et de mathématiques au début des degrés primaires: Une approche compréhensive de l'activité de l'enseignant généraliste [Comparative study of French and mathematics lessons in early school grades: A comprehensive approach of the generalist teacher activity]. Unpublished doctoral thesis. Université de Genève.

Englund, T. (2006). New trends in Swedish educational research. Scandinavian Journal of Educational Research, 50(4), 383-396.

Glaser, R. (1984). Education and thinking: The role of knowledge. American Psychologist, 39, 93-104.

Gueudet, G., \& Trouche, L. (2009). Towards new documentation systems for mathematics teachers? Educational Studies in Mathematics, 71, 199-218. 
Ligozat, F. (2011a). The determinants of the joint action in didactics: The text-action relationship in teaching practice. In B. Hudson \& M. A. Meyer (Eds.), Beyond fragmentation: Didactics, learning and teaching in Europe (pp. 157-176). Farmington Hills, MI: Barbara Budrich Publishers.

Ligozat, F. (2011b). The development of comparative didactics \& joint action theory in didactics in the context of the French «Disciplinary Didactiques». Paper presented in symposium «FachdidaktikEuropean perspectives» (coord. H. J. Vollmer). Network 27, Learning and teaching/Didactics. European Congress on Educational Research, Berlin http://archive-ouverte.unige.ch/unige:75023.

Ligozat, F., \& Schubauer-Leoni, M. L. (2010). The joint action theory in didactics: Why Do We Need It in the Case of Teaching and Learning Mathematics? In V. Durand-Guerrier, S. Soury-Lavergne, \& F. Arzarello (Eds.), Proceedings of the 6th congress of the European society for research in mathematics education. (pp. 1615-1624) Lyon: INRP http://www.inrp.fr/editions/editionselectroniques/cerme6/.

Ligozat, F., Wickman, P. O., \& Hamza, K. M. (2011). Using practical epistemology analysis to study the teacher and students joint actions in the mathematics classroom. In M. Pytlak, E. Swoboda, \& T. Rowland (Eds.), Proceedings of the 7th congress of the european society for research in mathematics education (pp. 2472-2481). Rzeszow: University of Rzeszow.

Marlot, C., \& Toullec-Thery, M. (2014). Normes professionnelles et épistémologie pratique de l'enseignant : Un point de vue didactique. Canadian Journal of Education/Revue canadienne de l'éducation, 37(4), 1-32.

Mercier, A. (2008). Pour une lecture anthropologique du programme didactique. Éducation et didactique, 2(1), 7-40.

Mercier, A., Schubauer-Leoni, M. L., \& Sensevy, G. (2002). Vers une didactique comparée. Revue Française de Pédagogie, 141(special issue), 5-16.

Mercier, A., Schubauer-Leoni, M., Donck, E., \& Amigues, R. (2005). The intention to teach and school learning: The role of time. In A.-N. Perret-Clermont (Ed.), Thinking time. A multidisciplinary perspective on time (pp. 141-154). Cambridge, MA: Hogrefe Publishing.

Meyer, M. A. (2012). Keyword: Didactics in Europe. Zeitschrift für Erziehungswissenschaft, 15(3), $449-482$.

Östman, L. (1998). How companion meanings are expressed by science education discourse. In D. A. Roberts \& L. Östman (Eds.), Problems of meaning in science curriculum (pp. 54-70). New York: Teacher College Press.

Remillard, J. T., Lloyd, G. M., \& Hermel-Eisenmann, B. A. (2009). Mathematics teachers at work: Connecting curriculum materials and classroom instruction. New York: Routledge.

Reuter, Y. (2007). La conscience disciplinaire. Éducation \& Didactique, 1(2), 55-71.

Roberts, D. A. (1988). What counts as science education? In P. J. Fensham (Ed.), Development and dilemmas in science education (pp. 27-54). New York: Falmer Press.

Schneuwly, B. (1994). Contradiction and development: Vygotsky and paedology. European Journal of Psychology of Education, 9, 281-291.

Schneuwly, B. (2011). Subject didactics: An academic field related to the teacher profession and teacher education. In B. Hudson \& M. A. Meyer (Eds.), Beyond fragmentation: Didactics, learning and teaching in Europe (pp. 275-286). Farmington Hills: Barbara Budrich Publishers.

Schneuwly, B., \& Dolz, J. (2009). Des objets enseignés en classe de français: Le travail de l'enseignant sur la rédaction de textes argumentatifs et sur la surbordonnée relative. Rennes: Presses universitaires de Rennes.

Schoenfeld, A. H. (1985). Mathematical problem solving. New York: Academic University Presse.

Schubauer-Leoni, M.-L., \& Leutenegger, F. (2005). Une relecture des phénomènes transpositifs à la lumière de la didactique comparée. Revue Suisse des Sciences de l'Education, 27(3), 407-429.

Schubauer-Leoni, M.-L., \& Leutenegger, F. (2009). Implicites dans l'étude des processus transpositifs. Comparaison de textes officiels pour l'enseignement des mathématiques et du français dans les premières années de la scolarité. In C. Cohen-Azria \& N. Sayac (Eds.), Questionner l'implicite. Les méthodes de recherches en didactique (pp. 243-259). Lille: Presses du Septentrion.

Schulman, L. S. (1987). Knowledge and teaching: Foundations for the new reform. Harvard Educational Review, 57, 1-22.

Schwab, J. (1978). Education and the structure of the disciplines. In I. Westbury \& N. Wilkof (Eds.), Science. Curriculum and liberal education. Selected essays (pp. 229-272). Chicago: Chicago University Press.

Sensevy, G. (2014). Characterizing teaching effectiveness in the Joint Action Theory in Didactics: An exploratory study in primary school. Journal of Curriculum Studies, 46(5), 577-610. 
Sensevy, G., \& Mercier, A. (2007). Agir ensemble: L'action didactique conjointe du professeur et des élèves. Rennes: Presses universitaires de Rennes.

Sensevy, G. Gruson, B \& Forest, D. (in this issue). On the nature of the semiotic structure of the didactic action. The Joint Action Theory in Didactics within a Comparative Approach.

Stevens, R., Wineburg, S., Herrenkhol, L. R., \& Bell, P. (2005). Comparative understanding of school subjects: Past, present and future. Review of Educational Research, 75(2), 125-157.

Stodolsky, S. (1988). The subject matters. Chicago: University of Chicago Press.

Stodolsky, S., Salk, S., \& Glaessner, B. (1991). Student views about learning math and social studies. American Educational Research Journal, 28(1), 89-116.

Thevenaz-Christen, T., \& Schneuwly, B. (2006). L'activité langagière comme objet enseigné. L'exploration aux moments de son émergence dans la forme scolaire. In B. Schneuwly \& $\mathrm{T}$. Thevenaz-Christen (Eds.), Analyse des objets enseignés (pp. 37-66). Le cas du français, Bruxelles: De Boeck.

Vollmer, H. J. (2014). Fachdidaktik and the development of generalised subject didactics in Germany. Education \& Didactique, 8(1), 23-34.

Valverde, G. A., Bianchi, L. J., Wolfe, R. G., Schmidt, W. H., \& Houang, R. T. (2002). According to the book: Using TIMSS to investigate the translation of policy through the world of textbooks. Dordrecht: Kluwer (Springer).

Warfield McShane, V. (2014). Invitation to didactique (2nd édn.). Dordrecht: Springer. http://www. springer.com/education+\%26+language/book/978-1-4614-8198-0

Wickman, P.-O. (2012a). Using pragmatism to develop didactics in Sweden. Zeitschrift für Erziehungswissenschaft, 15(3), 483-501.

Wickman, P.-O. (2012b). A comparison between practical epistemology analysis and some schools in French didactics. Éducation et didactique, 6(2), 145-159. 